\title{
O HERÓI INCÓMODO: UTOPIA E PESSIMISMO NO TEATRO DE HILDA HILST
}

\author{
Henrique Marques Samyn*
}

\begin{abstract}
RESENHA
MARTÍNEZ TEIXEIRO, Alva. O herói incómodo: utopia e pessimismo no teatro de Hilda Hilst. A Coruña: Dep. de Galego-Português, Francês e Linguística da Universidade da Coruña, 2009. [Arquivo Teatral Francisco Pillado Mayor]
\end{abstract}

Licenciada em Filologia Portuguesa pela Universidade de Santiago de Compostela e doutoranda na Universidade da Coruña, Alva Martínez Teixeiro vem tendo aos poucos reconhecido seu talento como ensaísta: à monografia que publicou em 2006 sobre Raduan Nassar (Maktub. Da Retórica na Ficçáo de Raduan Nassar) e ao seu instigante estudo sobre Vicente Risco (A pretensa nostalxia da autoridade, laureado com o IV Premio Ramón Piñeiro de Ensaio) vem agora somar-se este pertinente estudo sobre o teatro de Hilda Hilst, autora que é também o objeto de sua investigação de doutorado.

Diversamente do que pode sugerir o título, o ensaio de Alva Martínez não consiste propriamente num estudo desde o princípio direcionado para questões particulares no âmbito da obra dramática dessa emblemática autora paulista, mas sim numa análise mais vasta que acompanha a progressiva construção do teatro hilstiano; é no processo de leitura desse movimento constitutivo que aqueles motivos emergem como foco da atenção investigadora. Em decorrência disso, se $O$ herói incómodo é uma obra de valor para o especialista, representa por outro lado uma produtiva introdução para os pouco familiarizados com a produção teatral de Hilda Hilst.

Após um capítulo que apresenta a autora, conciliando dados biográficos e uma consistente apreciação de seu percurso ("A subversiva trajectória de uma megalómana"), Alva Martínez concentra-se nas primeiras incursões daquela pelas regiões do teatro. No segundo capítulo do livro ("As obras dramáticas hilstianas: quando Eros abandonou Thanatos"), a ensaísta analisa em traços gerais as oito peças de Hilst, escritas entre 1967 e 1969: A Empresa, O Rato no Muro, O Novo Sistema, o Auto da Barca de Camiri, A Morte do Patriarca, O Verdugo, O Visitante e As Aves da Noite, sublinhando a relação entre a construção dos personagens, sua muitas vezes ousada estrutura dramática e os questionamentos políticos e morais que encerram.

No terceiro capítulo -- de título "O teatro contra a ditadura: o modo hilstiano como desvio face à mímese" --, Alva Martínez apresenta uma contextualização histórica do teatro brasileiro desde o golpe de 1964 até meados da década de 1970, o que lhe permite avaliar como a obra de Hilst diverge do panorama dramatúrgico da época. A

\footnotetext{
* Doutorando em Literatura Comparada (Universidade do Estado do Rio de Janeiro).
} 
despeito de seu denso tratamento de assuntos políticos, a escritora segue uma trilha singular, rechaçando a estética realista e o aproveitamento imediato de temas históricos. Como analisa a pesquisadora, o teatro hilstiano representa um "desvio face à norma, sendo, portanto, resultado da adequação do instrumento comunicativo às suas finalidades estéticas e programáticas pessoais e caracterizando-se, fundamentalmente, pela complexidade do universo apresentado", estando esse vinculado a todo o universo literário da autora (p. 80).

Com esses subsídios, pode Alva Martínez empreender, em "Uma pertubadora metáfora do mundo: poeticidade e experimentalidade", uma leitura da estética característica da dramaturgia hilstiana, o que lhe permite falar em termos de um "híbrido 'teatro-poesia'" e aproximar a autora paulista de nomes como Keats, Eliot, João Cabral e Renata Pallottini (p. 81). O tratamento do tempo e do espaço, a construção dos cenários e o uso de recursos simbólicos autorizam que se considere a obra de Hilst como uma contínua experimentação em torno de temas fundamentais: o amor, a liberdade, a vida.

No quinto capítulo ("O herói redentor e o desconforto da vontade messiânica"), a investigadora faz emergir seu tema central, avaliando que "o paradigma de figura trágica hilstiana é a do herói que redime os outros -- a humanidade -- com a própria morte" (p. 99). Figuras inadaptadas e desajustadas socialmente, os heróis hilstianos inscrevem-se em mundos estruturados de forma dicotômica, marcados por uma tensa clivagem entre o individual e o coletivo. O que está em jogo é o emprego de um procedimento particular para a construção dos personagens (que Alva Martínez prossegue analisando no sexto capítulo: "O trágico trânsito das personae dramáticas"), mediante o qual o outsider/revolucionário é "submetido a um profundo processo de particulatização e de subjectivação" (p. 139). Dessa forma, eles surgem à maneira de mártires que, sempre fiéis a uma densa solidez moral, transgridem a lei social em nome dessa moralidade superior. Deriva daí um forte pessimismo, uma distopia derivada do "divórcio mais radical entre o homem e o seu sistema moral" (p. 160), elemento analisado no sétimo capítulo do estudo ("A antiutopia como uma outra escatologia").

Como observa Alva Martínez no capítulo com que encerra o livro ("À maneira de conclusão"), o teatro hilstiano "postula-se artisticamente como testemunho do exílio do homem no mundo contemporâneo" (p. 186). Fornecendo novas leituras em torno desse pertinente assunto, $O$ herói incómodo representa uma valiosa contribuição para a bibliografia em torno da obra de Hilda Hilst, em que há ainda muito a ser compreendido e desvelado. 